<原落 $>$

$$
\begin{gathered}
\text { インターフェロン治療無効の C 型慢性肝炎に対するインター } \\
\text { フェロンと強力ネオミノファーゲン C 併用療法の有用性 }
\end{gathered}
$$

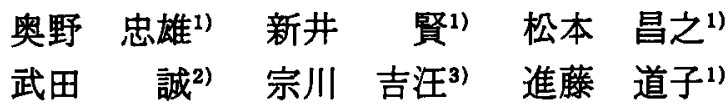

\begin{abstract}
要 旨：インターフェロン (IFN) 治療無効の C 型慢性肝炎 8 例 (CAH 7 例, $\mathrm{CPH} 1$ 例) K IFN- $\alpha$ （6MU/日）と強力ネオミノファーゲンC (SNMC, $80 \mathrm{~m} l /$ 日) の併用療法を行いその有 効性を治㞠前後の血清 HCV RNA と Knodell らの HAI score の变化から検討した. 初回 IFN 単独治療では ALT 值の正常化が想められなかったが，その平均减少率は約40\%と有意（p< 0.01)の低下であった。一方, IFN と SNMC 併用療法では 1 例でALT 値の正常化を認め，そ の平均减少率は約70\%と有意（ $\mathrm{p}<0.01 ）$ の低下を認めた. HAI score は IFN 単独治療時に有 意 $(\mathrm{p}<0.005)$ の改善を認めたが，単独治療終了時と併用療法終了時を比較しても有意の改善 が認められなかった，HCV RNA titer の変化では IFN 単独治療および併用療法前後でともに 有意の低下を諰めなかった．以上の結果から IFN 治療無効の C 型慢性肝炎に対して併用療法 は単独治療に比しより著しいALT 值の減少を認めるもウイルス学的ならびに組織学的改善の 根拠は認めなかった。
\end{abstract}
索引用語：C 型慢性肝炎
IFN 治療無効例
IFN と SNMC 併用療法 HCV RNA
HAI score

はじめに

インターフェロン（IFN）治療によりC型慢性肝炎 の約 $48 \%$ ８5\%に血清トランスフミナービ值の正常化 が認められ ${ }^{1,2)}$ ，その約 $80 \%$ 症例で血清 HCV RNA が陰性であることが報告されている3,4. しかし，IFN 治㞠を中止するとその50\%以上の症例でトランスフミ ナーゼの再上年や HCV RNAの再陽性化がみられ ๖.

一方，C 型慢性肝炎の中には十分量の IFN 治療にも かかからずトランスフミナーゼの正常化を認めない症 例る少なからす゚存在する、また，IFN 治療無効のC型 慢性肝资の多くは組織学的にも進行しており，短期間 に肝硬变へ進展する可能性の高い疾患である.しかし， 一定の治療法はなく有効な治寮法の開発が模索されて いるのが現状である，今回，我々はIFN 治療無効の C 型慢性肝资にIFNと強力ネォミノファーダンC

1)明石市立市民病院内科

2)洛和会丸太町病院内科

${ }^{31}$ 京都工芸織維大学生物工学

〈受付日1993年8月18日>
（SNMC）との併用療法を行いその有効性を検討した. 対象および方法

1991年1月からら1992年12月まで 2 年間に明石市立 市民病院内科に入院した患者のうちC型慢性肝炎と 診断され肝生検を施行し $\alpha$ 型 IFN（IFN- $\alpha$ ）治療を 行ったのは153例である。このちち IFN 投与中および 治㞠終了後。血清 alanine aminotransferase (ALT) 値の正常化を認めなかったのは35例であった。ここの35 例の $5 ち 8$ 例に初回 IFN 治療終了 24 週後にIFN と SNMC との併用療法を行った。対象は男性 5 例，女性 3 例の 8 例である(Table 1). 年龄は41歳から65歳(平 均53.4藏)であった。全例で HCV 抗体 (anti-HCV) が陽性であった. 1 例が第 2 世代の anti-HCV (Ortho Diagnostic System)のみ陽性であり，残りの 7 例では C100-3抗体 (Ortho Diagnostic System) が陽性であっ た.

輸血歴は1例で認められるす，7例では認めなかっ た。抗核抗体 (ANA) および抗平滑筋抗体 (SMA) は 治療開始前に全例で測定し，ANAは 1 例で陽性（80 倍) SMA は 2 例で陽性（40倍と80倍）であった。 
Table 1 Characteristics of patients with chronic hepatitis $C$ who were resistant to the initial IFN therapy alone.

\begin{tabular}{|c|c|c|c|c|c|c|c|}
\hline Case no. & Sex & Age (yr.) & $\begin{array}{l}\text { Response to } \\
\text { IFN therapy a }\end{array}$ & Histology & anti-HCV & $\begin{array}{l}\text { Serum HCV RNA } \\
\text { (reciprocal titer) }\end{array}$ & $\begin{array}{c}\text { HCV } \\
\text { genotype b }\end{array}$ \\
\hline 1 & $M$ & 41 & NR & CAH, moderate & + & 10 & n \\
\hline 2 & $M$ & 60 & NR & CAH, severe & + & 100 & I \\
\hline 3 & $M$ & 65 & NR & CAH, severe & + & 10 & v \\
\hline 4 & $\mathbf{M}$ & 52 & NR & CAH, severe & + & 100 & प \\
\hline 5 & $F$ & 43 & NR & $\mathrm{CPH}$ & + & 10 & a \\
\hline 6 & $\mathbf{F}$ & 47 & NR & CAH, severe & + & 1 & v \\
\hline 7 & $F$ & 58 & NR & CAH, severe & + & 10 & प \\
\hline 8 & $M$ & 61 & NR & CAH, severe & + & 100 & 口 \\
\hline
\end{tabular}

NR : non-responder. CAH : chronic active hapatitis, CPH : chronic porsistont hepatitis apriar to the combined therapy of IFN and SNMC. B HCV genotypes were determined according to the methods of Okamoto H. et al., J Gen Virol, 1992

肝生検は IFN 単独治療前後と IFN と SNMC との 併用㞠法終了直後に施行し, 組織詥断は HE 染色と線 維染色標本を中心にヨーロッパ分類にに従って行っ た. IFN 治療開始前の組織診断は 6 例で chronic active hepatitis (CAH), severe (2B), 1 例で CAH, moderate (2A), 1 例で chronic persistent hepatitis (CPH)であった。 また, Histological Activity Index (HAI) score は Knodell ら6)の方法に従って行った.

血清 HCV RNAの测定は血清50 $\mu l$ から guanidium-isothiocyanate-phenol-chloroform 法に $\tau$ 抽出し, HCV genom $95^{\prime}$ non-coding region $\sigma$ primersを用いた RT-PCR 法いにて行った. 1st PCR に用いた primer の sequence は sense (no. 37〜59)： 5'-GAGGAACTACTGTCTTCACGCAG-3'), antisense (no. 310 -332) : 5' -CATGGTGCACGG. TCTACGAGACC-3') で，2nd PCR に用いた primer は sense：1st PCR に用いたと同様, anti-sense (no. 280 -302) : 5'-GCACTCGCAAGCACCCT. ATCAGG-3')である. PCRの program は $42^{\circ} \mathrm{C} て ゙ 30$ 分 間逆転写反応に続いて 25 cycles $\left(95^{\circ} \mathrm{C} て ゙ 30\right.$ 秒, $55^{\circ} \mathrm{C}$ で 1 分， $72^{\circ} \mathrm{C} て ゙ 1$ 分）のlstPCRを行い，2nd PCR は1st PCR と同様に35cycles 行った. PCR product (266bp) は ethidium bromide stained $の$ agarose gel を用いた 電気泳動にて解析した. HCV RNA titer は抽出 RNA を連続10倍希积することにより決定しだ． HCV genotype はOkamotoら》の方法に従って typespecific primerを用いた PCR 法にて測定した。

IFN 治療珄初回 IFN- $\alpha(\mathrm{rFIN}-\alpha$ 2a 6 例, HLBI 2
例) 600 万国際単位 (6MU) を筋注にて週 3 回, 12週間 投与した（総投与量は216MU)。初回 IFN 単独治療終 了 24 週後に IFN- $\alpha$ (rIFN- $\alpha 2 a 6$ 例, HLBI 2 例) $6 \mathrm{MU}$ と SNMC $80 \mathrm{~m} l$ を同日, 週 3 回, 24 週間投与した.IFN の総投与量は432MU であった，SNMCは静注投与で 行った.

治療前後での数值の有意差検定は paired t-testに

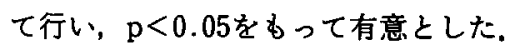

\section{結 果}

\section{1. 血清 ALT 值の变化 (Fig. 1)}

IFN 単独治療前の ALT 值の平均 (meantSD) は $219.9 \pm 67.9 \mathrm{IU} / l(102 \mathrm{IU} / l$ から300IU/l) であった。 治療後の ALT 值の平均值は $134.5 \pm 53.2(72 \mathrm{IU} / l$ か ら $195 \mathrm{IU} / l$ ) であり, IFN 投与前後で約40\%の ALT 值 の減少を認め, その减少率は有意 $(\mathrm{p}<0.01)$ の低下で あった。

一方, IFN と SNMC との併用療法前後の ALT 值 は治療前の平均値192.8 $\pm 119.91 \mathrm{IU} / l(621 \mathrm{IU} / l$ から $409 \mathrm{IU} / l$ ) から治療後に60.3土16.9IU $/ l$ (33IU $/ l$ から $88 \mathrm{IU} / l)$ 上減少し，その減少率は約70\%であり，有意 （p<0.01）の减少であった. また, 併用㞠法終了後の $\mathrm{SNMC} 80 \mathrm{~m} l$ 週 3 回投与12週間後の ALT 值の平均値

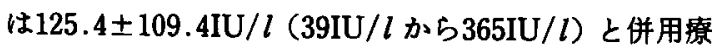
法終了時に比し上昇していたが梳計学的には有意の上 昇ではなかった（Fig. 1).

2. HAI score $の$ 变化 (Fig. 2)

HAI score は IFN 単独治療開始前に 1 例 (CPH) て 7, 残りの 7 例(CAH2A 1 例, CAH2B 6 例)では12 


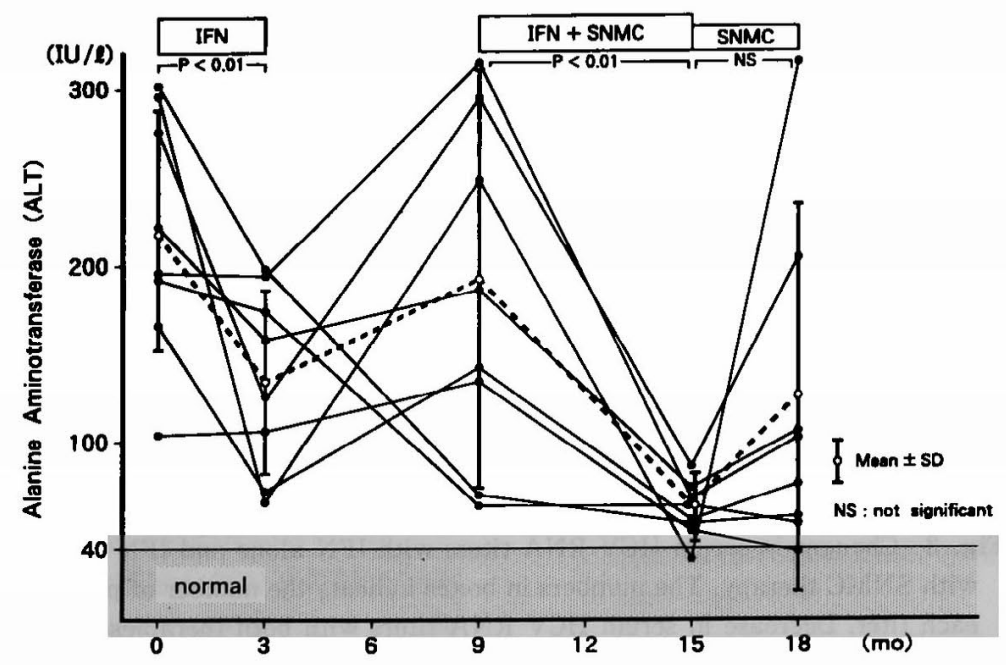

Fig. 1 Changes in serum alanine aminotransferase (ALT) levels with IFN alone and IFN combined SNMC therapy. There was $40 \%$ reduction in ALT levels with IFN alone therapy, while $70 \%$ reduction with IFN combined with SNMC therapy. Both reduction rates were significant $(p<0.01)$

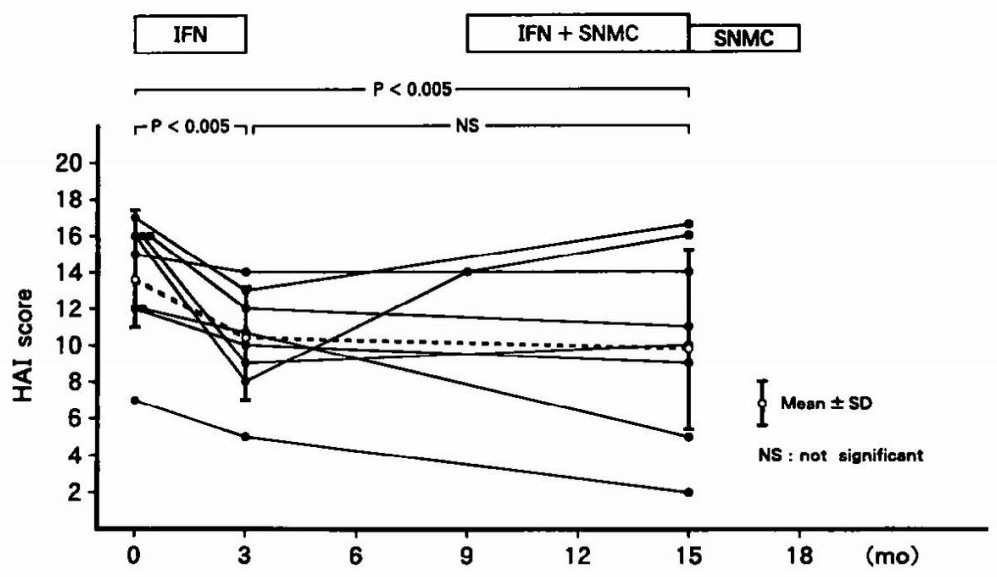

Fig. 2 Changes in histological activity index (HAI) score by Knodell et al. with IFN alone and IFN combined with SNMC therapy. HAI score decreased from $13.9 \pm 3.4$ to $10.1 \pm 3.1$ with IFN alone therapy $(p<0.005)$, while there was no significant decrease with IFN combined with SNMC therapy.

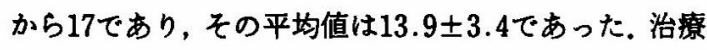
終了時に HAI score は 5 から14にまで减少し，その平 均値は10.1土3.1であり, 統計学的に有意 $(\mathrm{p}<0.01)$ の低下であった。

一方, IFN と SNMC との併用療法終了時の HAI

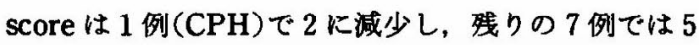
から16であった。併用療法終了時の HAI score の平均
值は10.4士5.0であり, IFN 単独治㞠終了時の10.1士 3.1 と比較して統計学的な有意差は認めなかったか， IFN 治療開始前と比較すると有意 $(\mathrm{p}<0.005)$ の低下 を認めた (Fig. 2).

3. 血清 HCV RNA の変化 (Fig. 3)

血清 HCV RNA は IFN 単独治㞠開始前全例で陽性

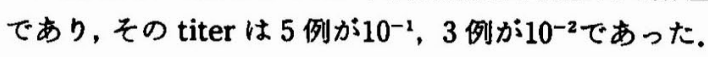




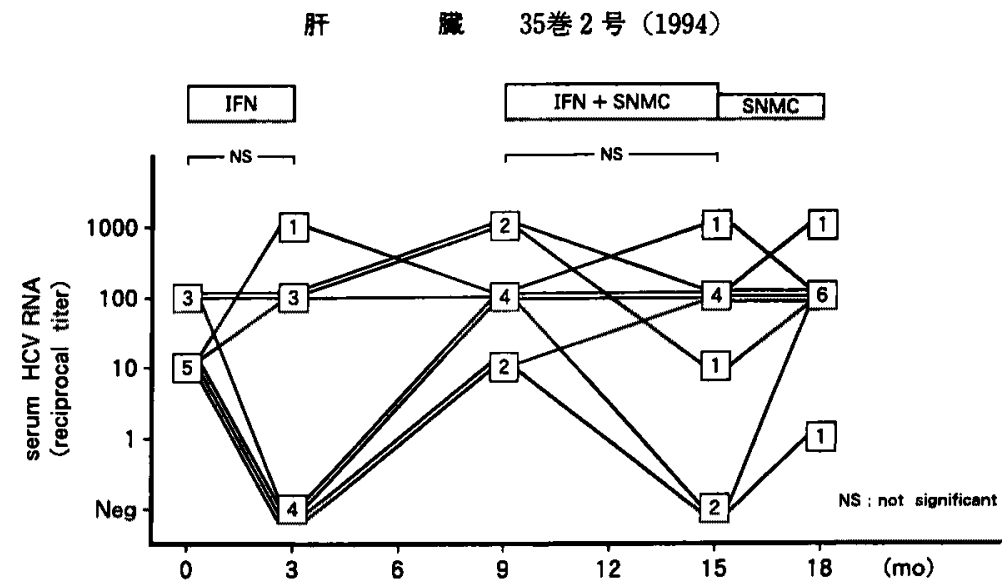

Fig. 3 Changes in serum HCV RNA titers with IFN alone and IFN combined with SNMC therapy. The numbers in boxes indicate the number of patients at each titer. Decrease in serum HCV RNA titers with both therapies were not significant.

また, HCV genotypeは全例でII型であった（Table 1). 治療終了時に HCV RNA は 4 例 (50\%) で陰性化 し， 4 例で陽性であった. HCV RNA が陽性であった 4 例の HCV RNA titer は 1 例が $10^{-3}, 3$ 例が10-2 で あり, 治療前後での HCV RNA titer の統計学的な有 意差を認めなかった。

一方, IFN と SNMC との併用療法開始前には全例 で HCV RNA は陽性であり, その HCV RNA titer は 2 例が $10^{-3} ， 4$ 例が $10^{-2}, 2$ 例が10-1 であった。併用療 法終了時には 2 例で陰性化し，残りの6 例では陽性で あった，HCV RNAが陽性であった 6 例の HCV

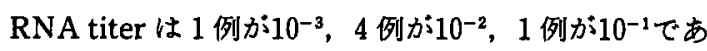
り, 治療前後での HCV RNA titer の統計学的な有意 差は認められなかった。また，併用㞠法終了後，12週 間のSNMC 単独治療では HCV RNA は全例で陽性 であり，HCV RNA titerは 1 例が $10^{-3} ， 6$ 例が $10^{-2}$, 1 例10゚であった (Fig. 3).

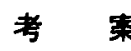

SNMCは慢性肝资に対して血清トランスフミナー ゼの有意の低下作用を有することが二重盲梌法により 報告されている8. また, SNMCはIFN 誘起作用があ

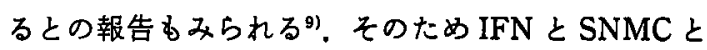
の併用療法は IFN 単独治療に比しょり高い治療効果 が得られる可能性が考えられる。

今回, 我々はC 型慢性肝炎に IFN 治療を行らも血 清トランスフミナーゼ值の正常化を認めなかった IFN 治療無効の C 型慢性肝炎に IFN と SNMC (大量 投与）との併用療法を行いその有効性を治療前後の血
清 HCV RNA と肝組織所見の䇅化を中心に検討し た。当施設で1991年 1 月から1992年12月までの 2 年間 に153例のC型慢性肝炎にIFN- $\alpha$ の治療を行いIFN 投与期間中お上び投与終了後も血清トランスフミナー ぜ值の正常化を認めなかったのは35例であり，その頻 度は22.9\%であった。このらち8 例に IFN 単独治療後 にIFN と SNMC との併用療法を行った，治潦開始前 の肝組織䥻断では 6 例が CAH, severe (2B), 1 例が $\mathrm{CAH}$, moderate (2A), 残りの 1 例は $\mathrm{CPH}$ であり, IFN 治療無効症例の多くは組織学的に進行した慢性 活動性肝炎であった，また，浩燎開始前の HAI score でも $\mathrm{CPH}$ の 7 を除くと 7 例では12から17であり，そ の平均は13.9土3.4と高い scoreであった。

一方，血清 HCV RNA は治療開始前に全例で陽性 であり，HCV RNA titer は $10^{\circ}\left(10^{3} \mathrm{copy} / \mathrm{m} l\right.$ に相当） から $10^{-2}\left(10^{-5} \mathrm{copy} / \mathrm{m} l\right.$ に相当)であった，最近，当 施設で肝生検にて診断を確認し得た C 型慢性肝炎47 例の血清 HCV RNA titer は10 から10-4でありその 平均は10-2であった. 従って, 今回の対象とした 8 例の IFN 治療無効のC型慢性肝炎での血清 HCV RNA titer がとくに高いとはいえなかった. IFN 単独治療終 了時には 4 例 (50\%) で HCV RNA は陰性化したが血 清 ALT 值の正常化は認められなかった。これら4例 は治療終了後に HCV RNA は再陽性化した。この所 見はIFN 治療終了直後の一過性の血清 HCV RNAの 陰性化がその後の肝炎の予後を予測する因子にはなら ないことを示唆するすのである.

一方，IFN 治撩無奻例に格いてもIFN 治療終了時 
にはALT 值は治療開始時と比較して約 $40 \%$ の减少を 認めた。 また, HAI score でも有意の改善を認めた。 IFN 治療無効との判定をどの時期にまたどのよらな 所見を持って行らかに関して一定の見解は得られてい ないため，今回の検討では IFN- $\alpha$ の12週間投与によっ ても血清 ALT 值の正常化を認めないものを IFN 治 療無効例と定義した。

また, IFN 治療無効と判定した 8 例の初回 IFN 治 療終了 24 週後にIFN とSNMC との併用潦法を24週 間行った。1 例で治療終了後にALTが正常化したが 治療終了 4 週間後に ALT 值の再上昇を認めた. 残り の 7 例では ALT 値の正常化を認めなかった，従って IFN 治療に対する有効性の判定を IFN 治療開始12週 間後に ALT 值の正常化をるって判定することに問題 はないすのと考えられる.

IFN治療に拈ける responder か non-responder か のウイルス学的な因子に治療開始前の血清 $\mathrm{HCV}$ RNA 量 ${ }^{10)} \mathrm{HCV}$ genotype $\mathrm{e}^{11,12)}$ 加関係しているとの 指摘がある.すなわち, non-responderでは $\mathrm{HCV}$ genotypeがII型であることや，HCV RNA 量が多い $\left(10^{5} \mathrm{copy} / \mathrm{m} l\right.$ 以上) との報告がみられる。しかし，今 回の検討では HCV genotype は全例でII 型であった が, IFN 単独治療開始前の HCV RNA titer は $10^{\circ}\left(10^{9}\right.$ copy $/ \mathrm{m} l)$ から $10^{-2}\left(10^{5} \mathrm{copy} / \mathrm{m} l\right)$ と比較的少なく従 来の報告とは異なっていた。

一方, IFN と SNMC との併用㞠法開始直前の $\mathrm{HCV}$ RNA titer は10-1から10-3であった，併用療法終了時 には約70\%の ALT 值の減少を認めた. HCV RNA は 治療終了時に 2 例で陰性化するす残りの6 例では陽性 (HCV RNA titer は10-1から10-3) であり併用療法前 後での統計学的な有意差は認められなかった。 また， 併用療法後の SNMC 単独治療中にむ HCV RNAの 減少を認めなかったことより SNMC は抗ウイルス作 用を有しないことが示された。

従って, IFN と SNMC との併用㞠法は IFN 単独治 療と比較してALT 值の明らかな低下を認めるるのの ウイルス学的並びに組䄉学的な改善は認められず， ALT 値の低下は主としてSNMCのステロイド放類 似の作用によるるのと推察される。

$$
\text { 結語 }
$$

IFN 治療無効のC 型慢性肝炎での IFN と SNMC （大量投与）との同時併用寮法により ALT 值の有意の 低下を認めるもウイルス学的並びに組織学的な改善は 諗めなかっった。
本論文の要旨は第29回日本肝贜学会総会 (奈良, 1993) に て発表した。

$$
\text { 文献 }
$$

1) Davis GL, Balart LA, Schiff ER, et al : Treatment of chronic hepatitis $C$ with recombinant interferon alfa. A multicenter randomized, controlled trial. N Engl J Med 321 : 1501-1506, 1989

2) DiBisceglie AM, Martin P, Kassianides G, et al : Recombinant interferon alfa therapy for chronic hepatitis $\mathrm{C}$. A randomized double-blind, placebo-controlled trial. N Engl J Med 321 : 1506-1510, 1989

3) Chayama K, Saitoh S, Araya $Y$, et al: Effect of interferon administration on serum hepatitis C virus RNA in patient with chronic hepatitis C. Hepatology 13 : 1040-1043, 1991

4) Shindo M, DiBisceglie AM, Cheung L, et al: Decrease in serum hepatitis $C$ virus RNA during alfa-interferon therapy for chronic hepatitis C. Ann Intern Med 115 : 700-704, 1991

5) International Group : Acute and chronic hepatitis revisited. Lancet 2: 914-919, 1977

6) Knodell RG, Ishak KG, Black WC, et al: Formation and application of a numerical scoring system for assessing histological activity in asymptomatic chronic active hepatitis. He. patology $1:$ 431-435, 1991

7) Okamoto H, Sugiyama $Y$, Okada S, et al: Typing hepatitis $C$ virus by polymerase chain reaction with type-specific primers: Application to clinical surveys and tracing infectious sources. J Gen Virol 73: 673-679, 1992

8）鈴木宏, 太田康幸, 瀧野辰郎, 他: 強力: ファーゲンCの慢性肝炎に対する治療効果につい て一二重盲愉法に上る検討一。医学のあゆ2 $102: 562-578,1977$

9）林 芳郎, 中田勝彦, 麻生 久, 他：クリチルリチ ン製剂のインターフェロン誘起作用。薬理と治療 $7: 3861-3864,1979$

10) Hagiwara H, Hayashi N, Mita E, et al: Quantitative analysis of hepatitis $\mathrm{C}$ virus RNA in serum during interferon alfa therapy. Gastroenterology $104: 877-883,1993$

11) Kanai K, Kato $M$, Okamoto $\mathrm{H}$ : $\mathrm{HCV}$ 
genotypes in chronic hepatitis $\mathrm{C}$ and response to interferon. Lancet $339: 1543,1992$

12) Yoshioka $K$, Kakumu $S$, Wakita $T$, et al : Detection of hepatitis $\mathrm{C}$ virus by polymerase chain reaction and response to interferon- $\alpha$ therapy : Relationship to genotypes of hepatitis C virus. Hepatology $16: 293-299,1992$

\title{
Efficacy of interferon combined glycyrrhizin therapy in patients with chronic hepatitis $\mathrm{C}$
}

\author{
Tadao OKUno*, Ken ARA广*, Masayuki Matsumoto*, Makoto TAKEDA**, \\ Yoshihiro SoKawA*** and Michiko SHINDo*
}

To assess the efficacy of interferon (IFN) combined with a large dose of glycyrrhizin (SNMC) therapy in patients with chronic hepatitis $\mathrm{C}$ who were resistant to interferon therapy alone, we studied 8 patients with chronic hepatitis $\mathrm{C}$ who didn't respond to the initial interferon therapy. Initially all of 8 patients received 6 million units of alpha-IFN intramuscularly three times a week for 3 months and their serum alanine transaminase (ALT) did not decrease more than $50 \%$ at the end of therapy and returned to pretreatment levels after therapy. Six months later all of these patients received alpha-IFN ( $6 \mathrm{MU}$ ) combined with $80 \mathrm{~m} l$ of SNMC intravenously three times a week for 6 months. Prior to the initial IFN therapy alone, all of patients were positive for anti-HCV and HCV RNA in serum. With IFN therapy, serum HCV RNA became negative in 4 of 8 patients and HAI score decreased significantly although their ALT levels did not decrease more than 50\%. While with IFN combined with SNMC therapy, ALT levels decreased approximately $70 \%$ in all patients (one became normal), serum HCV RNA became negative in 2 and HAI scores did not change significantly. There was no significant differences in decrease of HCV RNA titers and HAI scores between two therapy except ALT levels. These findings suggest that IFN combined SNMC therapy does not appear to be more beneficial than IFN therapy alone.

\footnotetext{
* Internal Medicine, Akashi Municipal Hospital Akashi (Hyogo)

** Internal Medicine, Rakuwakai Marutamachi Hospital (Kyoto)

*** Biotechnology, Kyoto Institutes of Technology (Kyoto)
} 